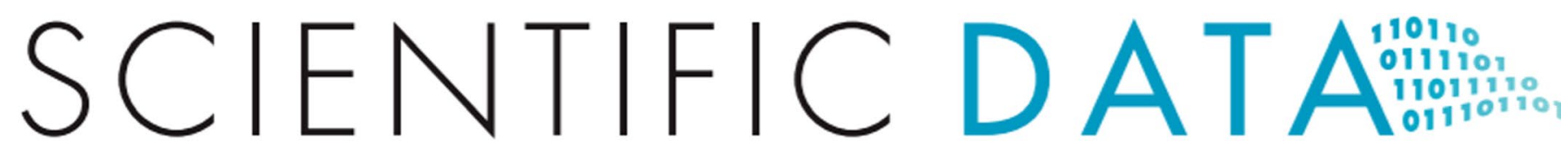

Check for updates

OPEN

Published online: 10 February 2020

\title{
Author Correction: Hybrid de novo whole-genome assembly and annotation of the model tapeworm Hymenolepis diminuta
}

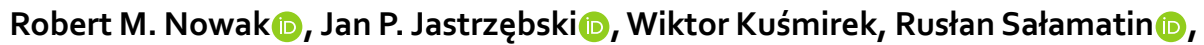
Małgorzata Rydzanicz, Agnieszka Sobczyk-Kopcioł, Anna Sulima-Celińska, Łukasz Paukszto $₫$, Karol G. Makowczenko $₫$, Rafał Płoski $₫$, VasylV. Tkach, Katarzyna Basałaji(i) \& Daniel Młocicki 10

Correction to: Scientific Data https://doi.org/10.1038/s41597-019-0311-3, published online 03 December 2019

Following publication, it was found that a part of the Acknowledgements section of this Data Descriptor was missing. This has now been corrected in the HTML and PDF versions.

(1) Open Access This article is licensed under a Creative Commons Attribution 4.0 International (c) License, which permits use, sharing, adaptation, distribution and reproduction in any medium or format, as long as you give appropriate credit to the original author(s) and the source, provide a link to the Creative Commons license, and indicate if changes were made. The images or other third party material in this article are included in the article's Creative Commons license, unless indicated otherwise in a credit line to the material. If material is not included in the article's Creative Commons license and your intended use is not permitted by statutory regulation or exceeds the permitted use, you will need to obtain permission directly from the copyright holder. To view a copy of this license, visit http://creativecommons.org/licenses/by/4.0/.

(C) (C) The Author(s) 2020 